\title{
Effects of Long-Chain Fatty Acids on Cytosolic Triacylglycerol Accumulation and Lipid Droplet Formation in Primary Cultured Bovine Mammary Epithelial Cells
}

\author{
T. Yonezawa, S. Yonekura, Y. Kobayashi, A. Hagino, K. Katoh, and Y. Obara \\ Department of Animal Physiology, Graduate School of Agricultural Science, \\ Tohoku University, Amamiyamachi, Sendai 981-8555, Japan
}

\begin{abstract}
Mammary epithelial cells have recently been shown to express and secrete leptin into milk and to accumulate triacylglycerol (TAG) in cytosol. We examined the effects on the accumulation of cytosolic TAG of free fatty acid addition to the medium bathing bovine mammary epithelial cells (bMEC). Both saturated (palmitic and stearic) and unsaturated (oleic and linoleic) fatty acids stimulated the accumulation of TAG in a concentration-dependent manner from 50 to $400 \mu M$ and the expression of mRNA expression for CD36, which is involved in the uptake and secretion of long-chain fatty acids. However, leptin mRNA expression and lipid droplet formation were significantly increased only by the addition of unsaturated, but not saturated, fatty acids. Interestingly, both types of fatty acids stimulated $\alpha$ s1-casein mRNA expression. These data suggest that the expression of leptin is related to droplet formation, whereas CD36 is related to cytosolic TAG accumulation, and that fatty acids or cytosolic TAG accumulation also have a role to accelerate differentiation of bMEC as shown by casein synthesis.
\end{abstract}

(Key words: long-chain fatty acid, triacylglycerol accumulation, lipid droplet, differentiation)

Abbreviation key: bMEC = bovine mammary epithelial cells, LCFA = long-chain fatty acids, MDGI = mammary derived growth inhibitor, TAG = triacylglycerol.

\section{INTRODUCTION}

Triacylglycerol (TAG) is stored as lipid droplets in adipocytes, and is the major energy reserve of the body. Lipid droplets consist of a large core of neutral lipid, primarily TAG, covered by a phospholipid monolayer. Mammary epithelial cells are known to accumulate

Received August 19, 2003.

Accepted March 30, 2004.

Corresponding author: T. Yonezawa; e-mail: yonet@bios.tohoku. ac.jp.
TAG in cytosol. During lactation, lipid droplet precursors are formed in the endoplasmic reticulum to make milk lipid globules. These precursors are budded from the endoplasmic reticulum, and comprise a TAG-rich core surrounded by a surface coat composed of proteins and polar lipid (Dylewski et al., 1984; Deeney et al., 1985; Mather and Keenan, 1998).

Leptin is the product of the ob gene and is secreted by adipocytes. It plays a pivotal role in regulating food intake, energy expenditure, and fat mass, presumably by acting on the hypothalamus or several tissues through its cognate receptor (Zhang et al., 1994; Bai et al., 1996; Friedman, 1997; Minokoshi et al., 2002). Adipocytes, which differentiate from preadipocyte precursor cells, are capable of lipid loading as well as the expression and secretion of myriad hormones and cytokines, such as leptin, tumor necrosis factor- $\alpha$ (Hotamisligil, 1999), adiponectin (Yamauchi et al., 2001), and resistin (Steppan et al., 2001). Leptin mRNA expression in adipocytes is dependent on the accumulation of cytosolic TAG (Vydelingum et al., 1995; Russell et al., 1998).

On the other hand, immature mammary epithelial cells also begin to differentiate into mature secretory epithelial cells during late gestation and the development is stimulated by lactogenic hormones that induce the synthesis and secretion of milk protein, fat, and lactose. It is clear that mammary epithelial cell differentiation may involve milk lipid accumulation in the cells. Knock-out mice, lacking the enzyme catalyzing the final esterification reaction in the biosynthesis of TAG (acyl-CoA: diacylglycerol acyl transferase), have normal serum lipid levels and apparently normal morphology for lipid loading in adipose tissues. Surprisingly, these mice cannot induce lactation without the onset of TAG synthesis in the mammary gland (Smith et al., 2000).

Moreover, recent studies have revealed that leptin is also produced by mammary epithelial cells and is present with lipid in milk, and that the downregulation of leptin expression occurs in a lactation-dependent manner (Aoki et al., 1999; Smith and Sheffield, 
2002). Leptin receptors have also been identified in mammary epithelial cells of sheep (Laud et al., 1999). Furthermore, leptin stimulates the proliferation of human breast cancer cells (MCF-7) (Dieudonne et al., 2002). These observations suggest that leptin plays an important role in mammary gland development.

On the other hand, CD36 (a fatty acid translocase) is unique in that it is highly expressed in adipocytes and mammary epithelial cells. Both the mammary gland and adipose tissue are actively involved in the uptake of long-chain fatty acids (LCFA) and the secretion of TAG. Recent data have shown that ligand activation of peroxisome proliferator-activated receptor$\gamma 2$ caused an inhibition of cell proliferation but an increase in extensive lipid accumulation via upregulation of CD36 in human breast cancer cell lines (Elstner et al., 1998).

In this study using bovine mammary epithelial cells (bMEC), we hypothesized that cytosolic TAG accumulation may be stimulated by the addition of FFA in a bathing medium, and it may affect the expression of leptin mRNA as well. We tested the addition of saturated and unsaturated FFA in the medium to measure TAG accumulation in the cytosol and mRNA expression of leptin and CD36 as well as $\alpha$ s1-casein and have discussed the relationship among them.

\section{MATERIALS AND METHODS}

\section{Cell Culture}

Bovine mammary epithelial cells were isolated from the mammary gland of a 102-d-pregnant Holstein heifer. The mammary tissue segments were digested by collagenase $(500 \mathrm{U} / \mathrm{mL})$ (E.C. 3.4.24.3, collagenaseII, Sigma-Aldrich, St. Louis, MO) for $30 \mathrm{~min}$ at $37^{\circ} \mathrm{C}$, and isolated cells were cultured in Dulbecco's modified Eagle's medium (Sigma-Aldrich) supplemented with $10 \%$ fetal calf serum, $2 \mathrm{mM}$ glutamine, $100 \mathrm{U} / \mathrm{mL}$ of penicillin, and $100 \mu \mathrm{g} / \mathrm{mL}$ of streptomycin under $5 \% \mathrm{CO}_{2}$ and air at $37^{\circ} \mathrm{C}$. Fluorescence-activated cell sorting analysis for cytokeratin expression in the cells revealed that they were composed of $92 \%$ mammary epithelial cells. In the present experiment, the cells were used between the 9th and 19th passages. The cells were seeded at $1.0 \times 10^{4}$ cells $/ \mathrm{cm}^{2}$ in a 6 -well plate and 100-mm dish (Corning, NY) and grown in the same conditions described above until confluency. Then, LCFA (Sigma-Aldrich) stimulation was performed for $24 \mathrm{~h}$ in Dulbecco's modified Eagle's medium containing $10 \%$ fetal calf serum, $2 \mathrm{mM}$ glutamine, 100 $\mathrm{U} / \mathrm{mL}$ of penicillin, and $100 \mu \mathrm{g} / \mathrm{mL}$ of streptomycin with $400 \mu M$ palmitate, stearate, oleate, or linoleate complexed to fatty acid-free BSA (6 mol of each LCFA sodium salt: $1 \mathrm{~mol}$ of albumin). In a concentration-dependent study, BSA concentration was fixed as described above and mixed with each LCFA at 50, 100, 200,300 , or $400 \mu M$.

\section{Measurement of the TAG Contents in the Cytosol}

Cultured cells on 6-well plates were washed twice with ice-cold PBS, scraped off into $0.4 \mathrm{~mL}$ of $25 \mathrm{mM}$ Tris-HCl (pH 7.5) and $1 \mathrm{~m} M$ EDTA, and then homogenized with a microhomogenizer (Ieda Trading, Tokyo, Japan). Protein concentrations were determined using a BCA protein kit (Pierce, Rockford, IL). The TAG in the cell lysate was extracted with the same volume of chloroform:methanol $(2: 1, \mathrm{vol} / \mathrm{vol})$ and quantified enzymatically using a Triglyceride G test kit (Wako, Osaka, Japan). The TAG contents were normalized for protein in each well. Each experiment was performed in triplicate and repeated at least 3 times.

\section{RNA Preparation}

After stimulations with LCFA, cells were washed twice with ice-cold PBS and scraped off into TRIsol reagent. Total RNA was isolated from the cells using the TRIsol extraction method according to the manufacturer's instructions (Gibco BRL, Grand Island, NY). Poly $(\mathrm{A})^{+}$mRNA was isolated from total RNA using a mRNA isolation kit (Miltenyi Biotec, Bergisch Gladbach, Germany). The concentration of isolated mRNA was determined from the optical density at $260 \mathrm{~nm}$ and its purity from a wavelength ratio of 260/280 $\mathrm{nm}$.

\section{cDNA Cloning and Semi-Quantitative Reverse Transcriptase PCR Analysis}

The cDNA fragments for leptin and G3PDH were obtained by RT-PCR as described previously (Yonekura et al., 2002). The cDNA fragments for CD36 and $\alpha$ s1-casein were obtained using the following primers: bovine CD36 forward, 5'-AACCACTTTCATCAGACC CG-3', reverse, 5'-ACGTGTCATCCTCAGTTCCA-3', and bovine $\alpha$ s1-casein forward, 5'-TCTTGTGGCTGT TGCTCTTG-3', reverse, 5'-GTGTGCCTAGTGGAAC GTAA-3'. The PCR generated 475- and 535-bp fragments of the bovine CD36 and $\alpha$ s1-casein gene, respectively. The first strand cDNA was synthesized with a random hexamer as a primer and then directly used for PCR reaction. The PCR amplification was done using the cDNA from 20 -ng Poly (A) ${ }^{+}$mRNA in a final volume of $50 \mu \mathrm{L}$. The reaction was performed using a commercial kit (Ready-to-go RT-PCR Beads, Amersham Pharmacia Biotech, Piscataway, NJ) according to the manufacturer's instructions. To ensure that cDNA 
of these genes was increased in an exponential manner, different numbers of cycles were run (PC-808 Astec, Tokyo, Japan). Finally, 26, 19, 32, and 40 cycles of amplification were chosen to study leptin, glyceraldehyde-3-phosphate dehydrogenase, CD36, and $\alpha$ s1casein mRNA expressions, respectively. In all assays, real-time negative amplification was included. The PCR products were analyzed in a $2.0 \%$ agarose gel, stained with ethidium bromide and photographed. These PCR products had been cloned and sequenced in accordance with the deposits in the Genbank/EMBL/ DDBJ database.

\section{Oil Red O Staining}

After stimulation, the cells were washed twice with ice-cold PBS, fixed in 10\% formalin for $10 \mathrm{~min}$, rinsed in distilled water, infiltrated into $60 \%$ isopropanol for $1 \mathrm{~min}$, and then stained with oil red $\mathrm{O}$ (Wako) for 15 min. The cells were counterstained with hematoxilin for 5 min by rinsing in quarter-saturated $\mathrm{LiCO}_{3}$.

\section{Statistics}

In all experiments, values are expressed as means \pm standard error of the mean, with at least 3 repeats in each experimental group. Statistical significance was estimated by means of one-way ANOVA followed by the Duncan's multiple range test. The test was considered significant at $P<0.05$.

\section{RESULTS}

\section{Accumulation of Cytosolic Triacylglycerol}

The addition of LCFA (palmitate, stearate, oleate, or linoleate) significantly increased cytosolic TAG contents compared with the control in primary cultured bMEC (Figure 1A). The TAG content of the control was $16.4 \pm 0.56 \mu \mathrm{g} / \mathrm{mg}$ of protein, which was significantly increased to $74.9 \pm 9.02,54.8 \pm 10.03,122.6 \pm 10.53$, and $109.1 \pm 3.61 \mu \mathrm{g} / \mathrm{mg}$ of protein, respectively, when cultured with palmitate, stearate, oleate, or linoleate. To determine whether the effect of FFA on bMEC has a physiological significance, we attempted to treat bMEC with various concentrations of FFA. The cells accumulated TAG in a concentration-dependent manner (Figure 1B). All fatty acids except linoleate caused a significant increase in cytosolic TAG accumulation at 200 to $400 \mu M$. Linoleate caused a significant increase in TAG accumulation at 50 to $400 \mu M$. Extending a culture period for 2 to $3 \mathrm{~d}$ did not increase TAG contents further, but rather caused a reduction in the TAG content (data not shown).

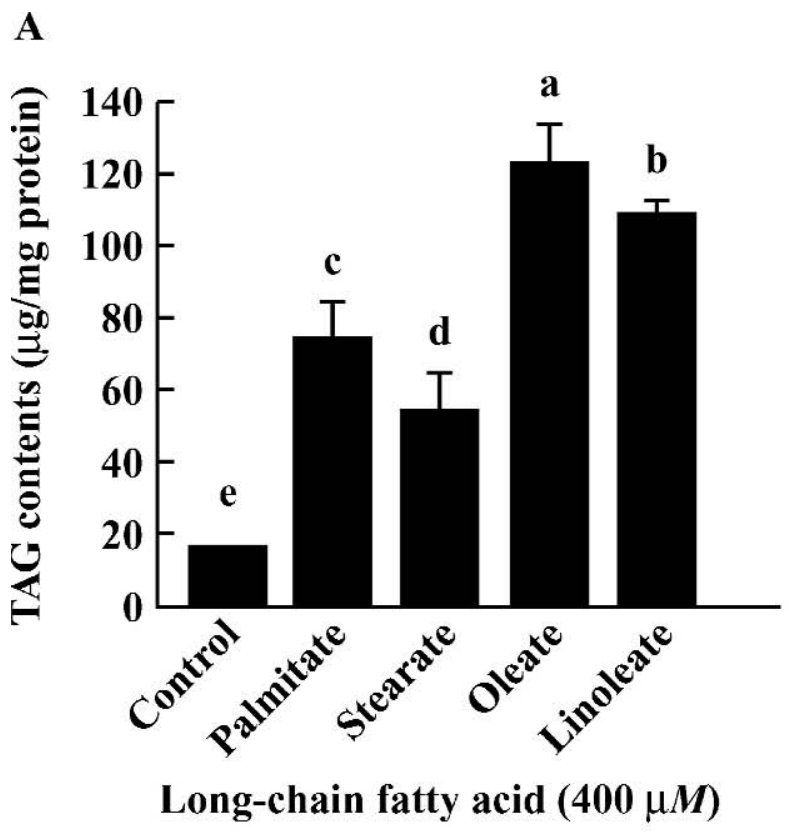

B

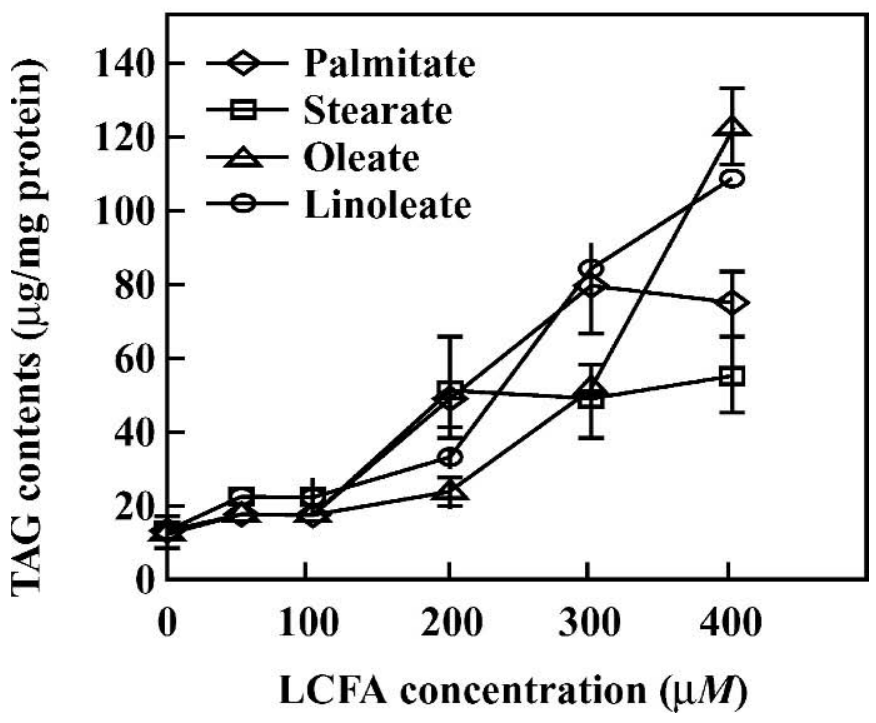

Figure 1. Effects of long-chain fatty acid (LCFA) on triacylglycerol (TAG) accumulation in bovine mammary epithelial cells (bMEC). A) The bMEC were treated with $400 \mu M$ palmitate, stearate, oleate, or linoleate for $24 \mathrm{~h}$. Values with different letters are statistically different $(P<0.05)$. B) The bMEC were treated with various concentrations of palmitate, stearate, oleate, or linoleate complex for $24 \mathrm{~h}$. The data are expressed as means \pm SEM $(n=3)$.

\section{Formation of Lipid Droplets}

To determine whether the formation of lipid droplets is paralleled by an increase in cytosolic TAG, we investigated lipid droplet formation in bMEC cultured with LCFA. Unexpectedly, lipid droplets were observed in the cells cultured with unsaturated fatty acids (oleate 
and linoleate), but not in those cultured with saturated fatty acids (palmitate and stearate) (Figure 2), although all LCFA induced an increase in TAG contents, as shown in Figure 1. Additionally, even in the cells treated for differentiation with the lactogenic hormones prolactin $(10 \mu \mathrm{g} / \mathrm{mL})$, insulin $(10 \mu \mathrm{g} / \mathrm{mL})$, and hydrocortisone $(10 \mu \mathrm{g} / \mathrm{mL})$, stimulation with saturated fatty acids did not form lipid droplets (data not shown). We also examined the effect of short- and mediumchain fatty acids on lipid droplet formation in bMEC and found that octanoate induced the formation of lipid droplets with lower TAG contents than those stimulated with LC saturated fatty acids (data not shown).

\section{Effects of Long-Chain Fatty Acids on Leptin, CD36, and $\alpha$ s1-Casein Expression}

In the next experiment, we examined whether the increase in TAG contents alters leptin mRNA expression. Leptin mRNA expression was significantly elevated in the cells cultured with unsaturated (oleate and linoleate), but not saturated (palmitate and stearate), fatty acids (Figure 3A). This elevation was about 1.3 and 1.4-fold more than that observed in the control in the cells treated with oleate and linoleate, respectively (Figure 3B).

We further tested whether exogenous fatty acids affect CD36 mRNA expression in bMEC. The CD36 mRNA expression was significantly elevated in the cells cultured with all LCFA. The expression was 4.2-, 4.9-, 5.9-, and 4.3-fold increased in the cells cultured with palmitate, stearate, oleate, and linoleate, respectively (Figure 3C).

Finally, we investigated effects of treatment of LCFA on casein mRNA expression. All LCFA induced the expression of $\alpha$ s1-casein mRNA (Figure 3A and D).

\section{DISCUSSION}

Mammary epithelial cells are well known as a cell type that accumulates TAG in the cytosol. Even in mammary epithelial cells, esterified fatty acids such as TAG are derived either from plasma lipids or by de novo synthesis from small molecule precursors. All the fatty acids are FFA when absorbed after LPL hydrolysis. In Figure 1B, exogenous LCFA are seen to induce the accumulation of cytosolic TAG in a concentrationdependent manner. Furthermore, CD36 mRNA level was markedly elevated by the LCFA treatment (Figure $3 \mathrm{C})$. These findings indicate that LCFA have a physiological significance for the accumulation of TAG via elevated CD36 synthesis in bMEC.

However, cellular metabolism appeared to be different between saturated and unsaturated fatty acids because whereas saturated fatty acids did not induce lipid droplet formation, unsaturated fatty acids did (Figure 2), although both types of fatty acids increased TAG accumulation (Figure 1). At first, we thought that lipid droplets, regardless of size, should be formed by LCFA treatment. However, the oil red O staining experiment revealed that the cells treated with saturated fatty acids did not form visible lipid droplets. A possible explanation is that some essential components required to form lipid droplets may not be expressed in the cytosol when treated with saturated fatty acids because droplet formation requires a TAGrich core surrounded by a surface coat composed of proteins and polar lipid (Dylewski et al., 1984; Deeney et al., 1985; Mather and Keenan, 1998). Otherwise, the uptake of saturated fatty acids may contribute to an elevated synthesis of membrane lipids such as sphingomyelin and ceramide. The LCFA transported into cells are converted into long-chain acyl-CoA by the action of acyl-CoA synthetases, and long-chain acyl-CoA is finally led to either the pathway for $\beta$ oxidation or TAG synthesis. Additionally, ceramide, a key molecule of apoptosis signaling, is generated either by de novo synthesis from palmitoyl-CoA or by degradation of sphingomyelin. In rat islets, increased cytosolic TAG contents stimulated by palmitate treatment are accompanied by increased ceramide content, resulting in an induction of $\beta$-cell apoptosis (Shimabukuro et al., 1998). In our preliminary experiment, culture with saturated fatty acid for 3 to $4 \mathrm{~d}$ abruptly reduced cell number, although cells cultured with unsaturated fatty acid were still alive and accumulated more cytosolic TAG content. This was reproduced again even at a lower concentration $(300 \mu M)$. It has been reported that human granulosa cells cultured with palmitate or stearate induced apoptosis ( $\mathrm{Mu}$ et al., 2001). Therefore, the finding that unsaturated fatty acids induced cytosolic TAG accumulation greater than that induced by saturated fatty acid may suggest that saturated fatty acids are subjected to another metabolic pathway, and not to either TAG synthesis or lipid droplet formation.

We hypothesized that cytosolic TAG accumulation is associated with the expression of leptin mRNA in bMEC, as already shown in adipocytes. Our finding showed that leptin mRNA expression was slightly but significantly elevated in the cells cultured with unsaturated fatty acids (Figure 3B). This finding suggests that leptin mRNA expression is associated with the formation of lipid droplets, but not with the accumulation of cytosolic TAG in bMEC. Recently, leptin has been shown to be present in human breast milk (Smith-Kirwin et al., 1998). In mice, leptin is secreted as a part of milk fat (Aoki et al., 1999). 
A

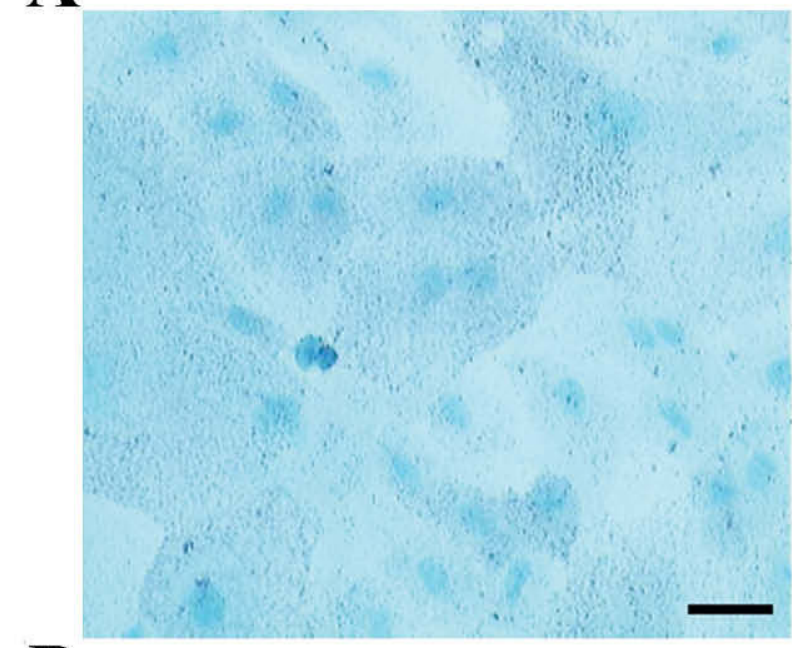

B

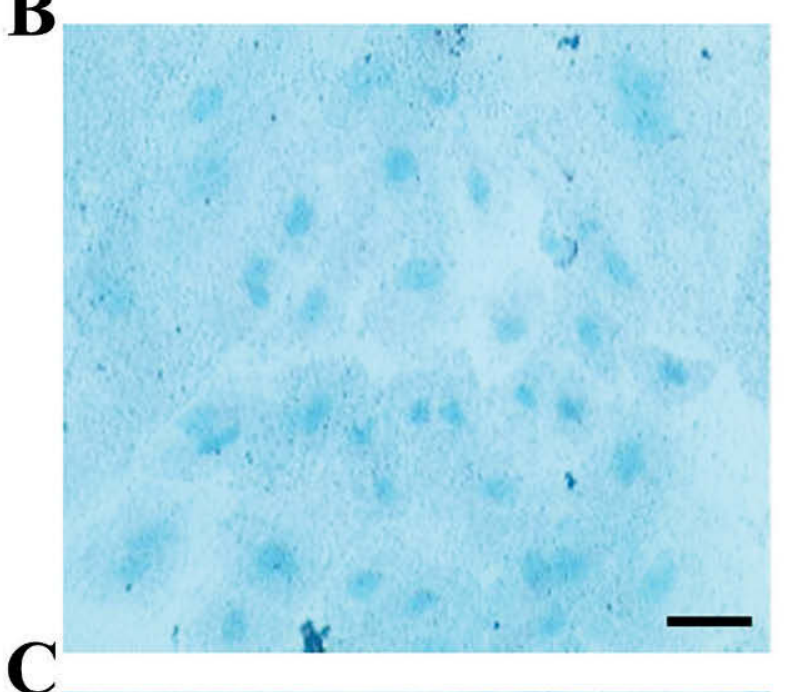

D

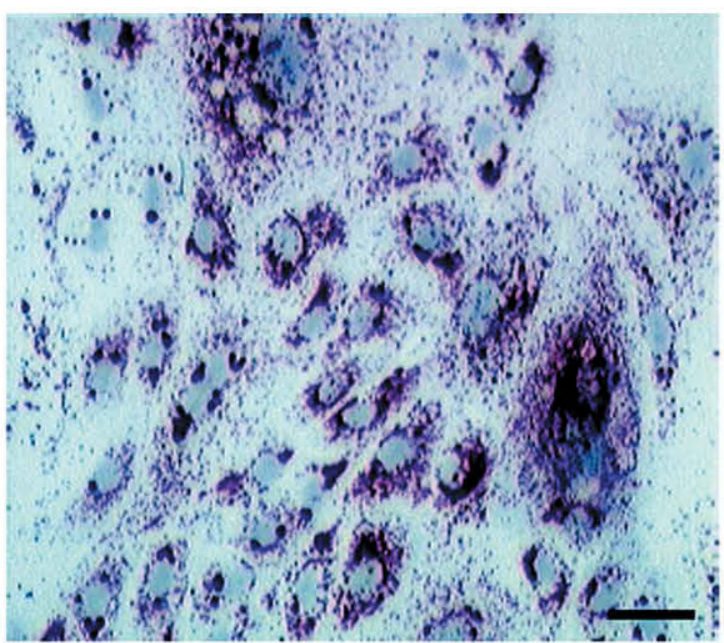

$\mathbf{E}$

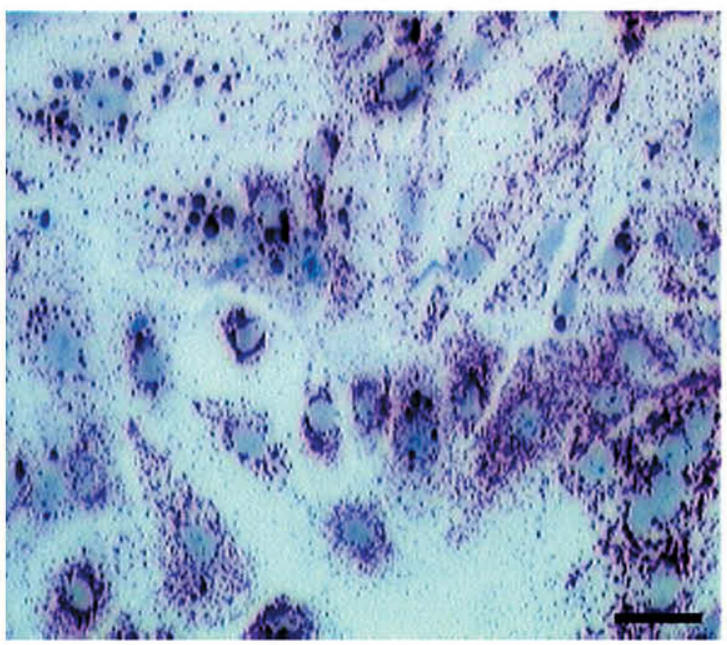

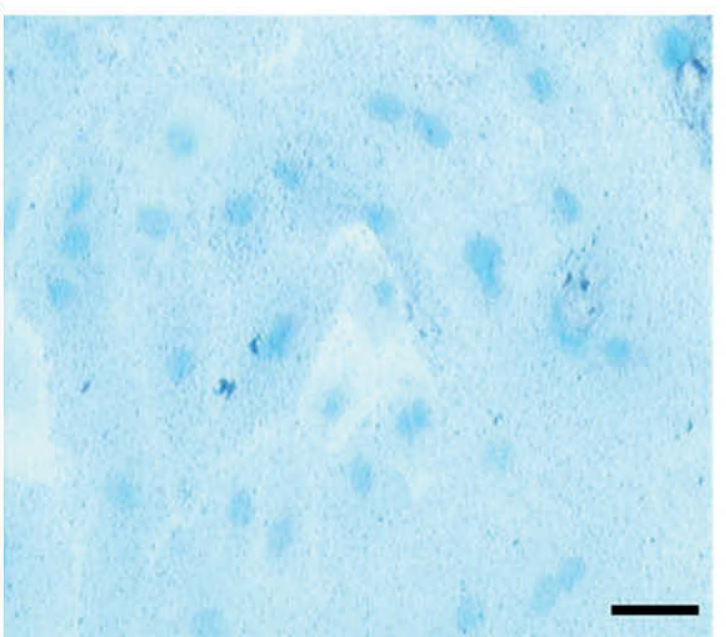

$\mathbf{F}$

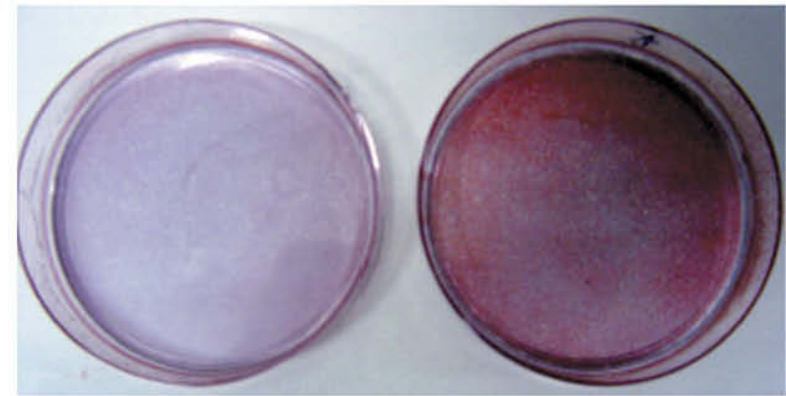

Control

\section{Oleate}

Figure 2. Effects of long-chain fatty acid (LCFA) on lipid droplet formation in bovine mammary epithelial cells (bMEC). Cells were cultured under the same conditions described for Figure 1A, and then stained with oil red $\mathrm{O}$ and hematoxilin. A) No LCFA; B) palmitate; C) stearate; D) oleate; E) linoleate $(400 \mu M)$. Bar indicates $10 \mu \mathrm{m}$. Results are representative of 3 separate experiments. F) The dish treated with or without oleate $(400 \mu M)$ were stained by oil red $\mathrm{O}$ and hematoxilin. 
A

Leptin

CD36
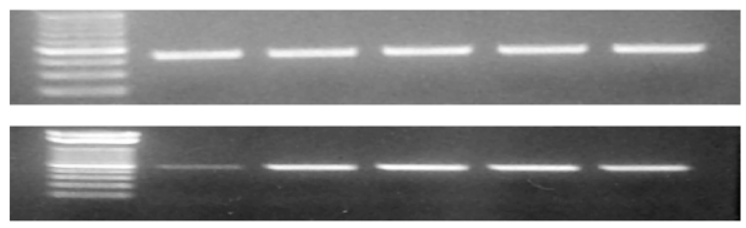

$\alpha s 1-c a s e i n$

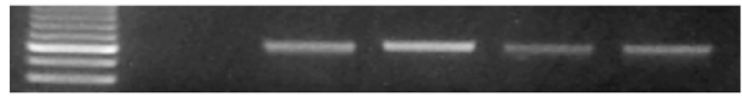

G3PDH

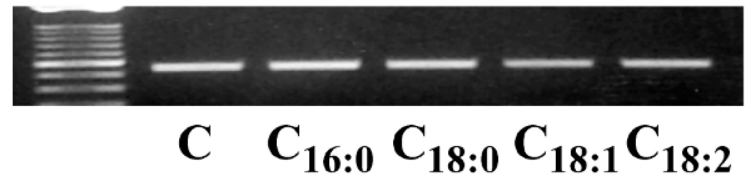

B

Leptin/G3PDH

C

CD36/G3PDH

D

\section{$\alpha$ s1-casein/G3PDH}

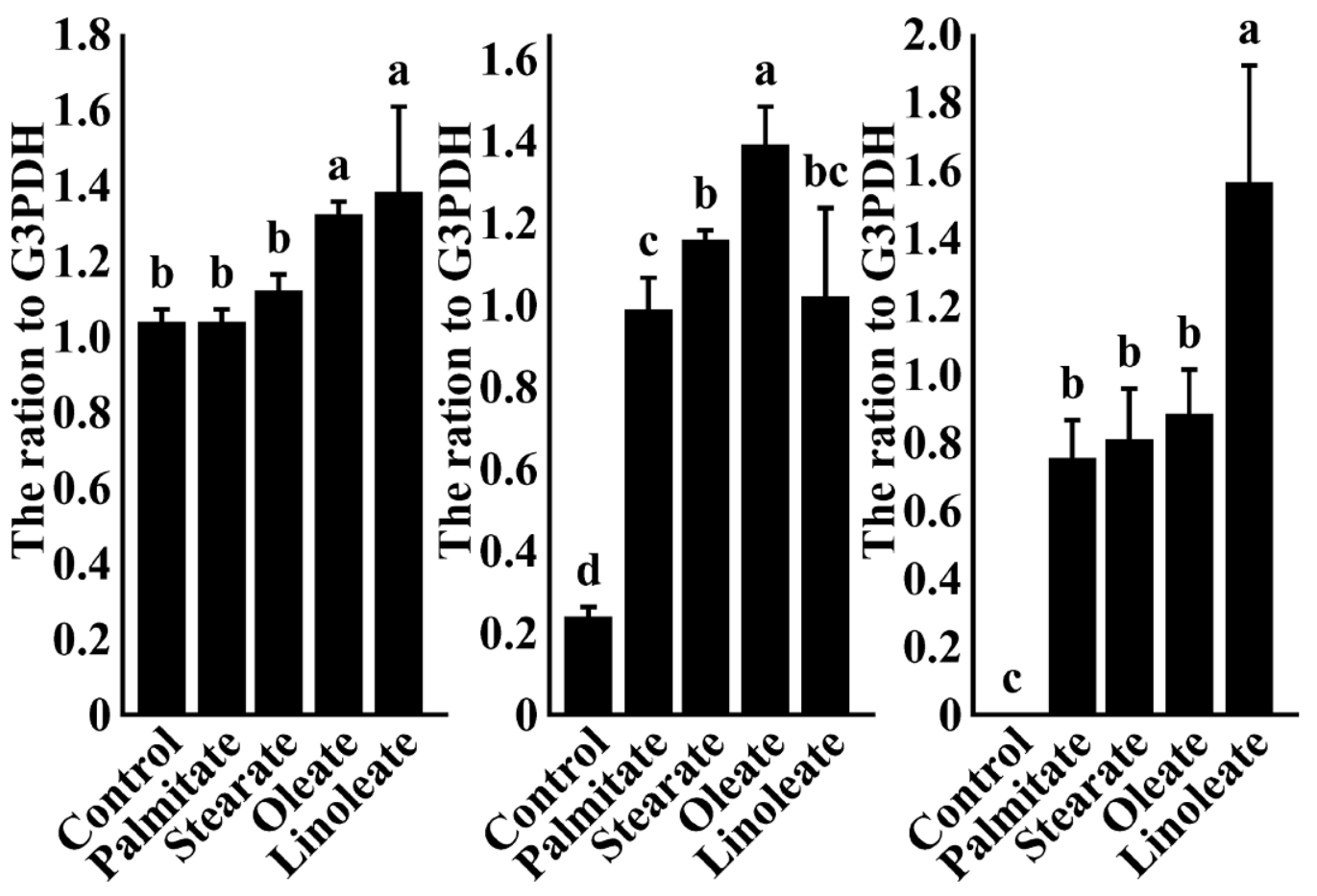

Figure 3. The expression of leptin, CD36 (a fatty acid translocase), $\alpha$ s1-casein, and G3PDH (glyceraldehyde-3-phosphate dehydrogenase) mRNA following long-chain fatty acid (LCFA) stimulation. A) Cells were cultured with palmitate, stearate, oleate, or linoleate at $400 \mu M$, or in the absence of LCFA. The mRNA was reverse-transcribed followed by PCR amplification with specific sets of primers for bovine leptin, CD36, $\alpha$ s1-casein, and G3PDH. The PCR products were run on a 2.0\% agarose gel and stained with ethidium bromide and were densitometrically analyzed. In $\mathrm{B}, \mathrm{C}$, and $\mathrm{D}$, the expression level of bovine leptin, CD36, and $\alpha$ s1-casein was normalized by that of G3PDH, respectively. The data are shown as means \pm SEM $(\mathrm{n}=3)$. The values with different letters are statistically different $(P<0.05)$.

Mammary epithelial cells begin to differentiate into mature cells in the presence of lactogenic hormones, inducing the synthesis and secretion of milk protein, fat, and lactose. Mammary epithelial cell differentiation may be related to milk lipid accumulation because the activation of peroxisome proliferator-activated receptor- $\gamma 2$ caused inhibition of proliferation and extensive lipid accumulation via the up-regulation of CD36 in human breast cancer cell lines (Elstner et al., 1998). Our results revealed that exogenous LCFA markedly 
enhanced the accumulation of cytosolic TAG and the expression of CD36 mRNA in bMEC. This clearly indicates that exogenous LCFA induce the expression of CD36, which plays a role in fatty acid translocation in various cells and plays a positive role in the uptake of LCFA in bMEC. Thus, it is likely that treatment with LCFA is able to differentiate bMEC. Actually, the expression of $\alpha$ s1-casein mRNA was markedly enhanced in association with the accumulation of cytosolic TAG in bMEC (Figure 3A), although the level of enhancement seemed lower observed with lactogenic hormones. This finding suggests that the accumulation of cytosolic TAG may be directly or indirectly related to the differentiation of mammary epithelial cells. A series of gene expression profiles was similar to that in cloned bMEC established in our laboratory (data not shown). Our assumption on the action of fatty acids is supported by a report showing that the overexpression of mammary-derived growth inhibitor, which was cloned in human mammary gland and identified as one of the fatty acid binding proteins, induced differentiation and a significant increase in the production of lipid droplets in human breast cancer cells and mouse mammary gland. Treatment with mammary-derived growth inhibitor was also accompanied by differentiation and increased $\beta$-casein expression (Wang et al., 2000). Furthermore, in bMEC, it is reported that MDGI/fatty acid binding protein interacts with CD36, these proteins having inhibitory effects on cell proliferation and increasing in a lactation-dependent manner (Spitsberg et al., 1995).

In summary, our present study revealed that LCFA induced the accumulation of cytosolic TAG in bMEC, although different effects were observed on lipid droplet formation between saturated and unsaturated fatty acids. Unsaturated fatty acids significantly enhanced the elevation of leptin mRNA expression, although both saturated and unsaturated fatty acids significantly enhanced the mRNA expression of CD36 and $\alpha$ s1-casein. To our knowledge, this study is the first report showing that exogenous FFA increase milk protein expression in addition to TAG accumulation in bMEC.

\section{ACKNOWLEDGMENTS}

We thank M. T. Rose (University of Wales, Aberystwyth, UK) for his contribution in the preparation of manuscript, and H. Aso (Laboratory of Functional Morphology, Tohoku University) for his helpful advice on oil red staining.

\section{REFERENCES}

Aoki, N., M. Kawamura, and T. Matsuda. 1999. Lactation-dependent down regulation of leptin production in mouse mammary gland. Biochim. Biophys. Acta 1427:298-306.
Bai, Y., S. Zhang, K.-S. Kim, J.-K. Lee, and K.-H. Kim. 1996. Obese gene expression alters the ability of $30 \mathrm{~A} 5$ preadipocytes to respond to lipogenic hormones. J. Biol. Chem. 271:13939-13942.

Deeney, J. T., H. M. Valivullah, C. H. Dapper, D. P. Dylewski, and T. W. Keenan. 1985. Microlipid droplets in milk secreting mammary epithelial cells: Evidence that they originate from endoplasmic reticulum and are precursors of milk lipid globules. Eur. J. Cell Biol. 38:16-26.

Dieudonne, M. N., F. Machinal-Quelin, V. Serazin-Leroy, M. C. Leneveu, R. Pecquery, and Y. Giudicelli. 2002. Leptin mediates a proliferative response in human MCF7 breast cancer cells. Biochem. Biophys. Res. Commun. 293:622-628.

Dylewski, D. P., C. H. Dapper, H. M. Valivullah, J. T. Deeney, and T. W. Keenan. 1984. Morphological and biochemical characterization of possible intracellular precursors of milk lipid globules. Eur. J. Cell Biol. 35:99-111.

Elstner, E., C. Müller, K. Koshizuka, E. A. Williamson, D. Park, H. Asou, P. Shintaku, J. W. Said, D. Heber, and H. P. Koeffler. 1998). Ligands for peroxisome proliferator-activated receptor $\gamma$ and retinoic acid receptor inhibit growth and induce apoptosis of human breast cancer cells in vitro and in BNX mice. Proc. Natl. Acad. Sci. USA 95:8806-8811.

Friedman, J. M. 1997. The alphabet of weight control. Nature $385: 119-120$.

Hotamisligil, G. S. 1999. The role of TNF- $\alpha$ and TNF receptors in obesity and insulin resistance. J. Int. Med. 245:621-625.

Laud, K., I. Gourdou, L. Bélair, D. H. Keisler, and J. Djiane. 1999. Detection and regulation of leptin receptor mRNA in ovine mammary epithelial cells during pregnancy and lactation. FEBS Lett. 463:194-198.

Mather, I. H., and T. W. Keenan. 1998. Origin and secretion of milk lipids. J. Mammary Gland Biol. Neoplasia 3:259-273.

Minokoshi, Y., Y.-B. Kim, O. D. Peroni, L. G. D. Fryer, C. Müller, D. Carling, and B. B. Kahn. 2002. Leptin stimulates fatty-acid oxidation by activating AMP-activated protein kinase. Nature 415:339-343.

Mu, Y.-M., T. Yanase, Y. Nishi, A. Tanaka, M. Saito, C.-H. Jin, C. Mukasa, T. Okabe, M. Nomura, K. Goto, and H. Nawata. 2001. Saturated FFA, palmitic acid and stearic acid, induce apoptosis in human granulosa cells. Endocrinology 142:3590-3597.

Russell, C. D., R. N. Petersen, S. P. Rao, M. R. Ricci, A. Prasad, Y. Zhang, R. E. Brolin, and S. K. Fried. 1998. Leptin expression in adipose tissue from obese humans: Depot-specific regulation by insulin and dexamethasone. Am. J. Physiol. 275 3Pt1:E507-E515.

Steppan, C. M., S. T. Bailey, S. Bhat, E. J. Brown, R. R. Banerjee, C. M. Wright, H. R. Patel, R. S. Ahima, and M. A. Lazar. 2001. The hormone resistin links obesity to diabetes. Nature 409:307-312.

Smith, S. J., S. Cases, D. R. Jensen, H. C. Chen, E. Sande, B. Tow, D. A. Sanan, J. Raber, R. H. Eckl, and R. V. Farese, Jr. 2000. Obesity resistance and multiple mechanisms of triglyceride synthesis in mice lacking Dgat. Nat. Genet. 25:87-90.

Smith, J. L., and L. G. Sheffield. 2002. Production and regulation of leptin in bovine mammary epithelial cells. Domest. Anim. Endocrinol. 22:145-154.

Shimabukuro, M., Y.-T. Zhou, M. Levi, and R. H. Unger. 1998. Fatty acid-induced $\beta$ cell apoptosis: A link between obesity and diabetes. Proc. Natl. Acad. Sci. USA 95:2498-2502.

Smith-Kirwin, S. M., D. M. O'Connor, J. Johnston, E. De Lancey, S. G. Hassink, and V. L. Funanage. 1998. Leptin expression in human mammary epithelial cells and breast milk. J. Clin. Endocrinol. Metab. 83:1810-1813.

Spitsberg, V. L., E. Matitashvili, and R. C. Gorewit. 1995. Association and coexpression of fatty-acid-binding protein and glycoprotein CD36 in the bovine mammary gland. Eur. J. Biochem. 230:872-878.

Vydelingum, S., G. Shillabeer, G. Hatch, J. C. Russell, and D. C. W. Lau. 1995. Overexpression of the obese gene in the genetically obese JCR: LA-corpulent rat. Biochem. Biophys. Res. Commun. 216:148-153. 
Wang, M., Y. E. Liu, J. Ni, B. Aygun, I. D. Goldberg, and Y. E. Shi. 2000. Induction of mammary differentiation by mammaryderived growth inhibitor-related gene that interacts with an omega-3 fatty acid on growth inhibition of breast cancer cells. Cancer Res. 60:6482-6487.

Yamauchi, T., J. Kamon, H. Waki, Y. Terauchi, N. Kubota, K. Hara, Y. Mori, T. Ide, K. Murakami, N. Tsuboyama-Kasaoka, O. Ezaki, Y. Akanuma, O. Gavrilova, C. Vinson, M. L. Reitman, H. Kagechika, K. Shudo, M. Yoda, Y. Nakao, K. Tobe, R. Nagai, S. Kimura,
M. Tomita, P. Froguel, and T. Kadowaki. 2001. The fat-derived hormone adiponectin reverses insulin resistance associated with both lipoatrophy and obesity. Nat. Med. 78:941-946.

Yonekura, S., K. Kitade, G. Furukawa, K. Takahashi, N. Katsumata, K. Kato, and Y. Obara. 2002. Effects of aging and weaning on mRNA expression of leptin and CCK receptors in the calf rumen and abomasums. Domest. Anim. Endocrinol. 22:25-35.

Zhang, Y., R. Proenca, M. Maffei, M. Barone, L. Leopold, and J. M. Friedman. 1994. Positional cloning of the mouse obese gene and its human homologue. Nature 372:425-432. 